\title{
The annual ammonia budget of fertilised cut grassland - Part 1: Micrometeorological flux measurements and emissions after slurry application
}

\author{
C. Spirig ${ }^{1, *}$, C. R. Flechard ${ }^{2}$, C. Ammann ${ }^{1}$, and A. Neftel ${ }^{1}$ \\ ${ }^{1}$ Agroscope Reckenholz-Tänikon ART, Swiss Federal Research Station, Zürich, Switzerland \\ ${ }^{2}$ Institut National de Recherches Agronomiques (INRA), Soils, Agro- and Hydro-Systems (SAS), Rennes Cedex, France \\ *now at: MeteoSwiss, Federal Office of Meteorology and Climatology, Zürich, Switzerland
}

Received: 3 September 2009 - Published in Biogeosciences Discuss.: 7 October 2009

Revised: 16 January 2010 - Accepted: 24 January 2010 - Published: 8 February 2010

\begin{abstract}
Two commercial ammonia $\left(\mathrm{NH}_{3}\right)$ analysers were customised to allow continuous measurements of vertical concentration gradients. The gradients were used to derive ammonia exchange fluxes above a managed grassland site at Oensingen (Switzerland) by application of the aerodynamic gradient method. The measurements from July 2006 to October 2007 covered five complete growth-cut cycles and included six applications of liquid cattle slurry. The average accuracy of the flux measurements during unstable and near-neutral conditions was $20 \%$ and the detection limit was $10 \mathrm{ngNH}_{3} \mathrm{~m}^{-2} \mathrm{~s}^{-1}$. Hence the flux measurements are considered sufficiently accurate for studying typical $\mathrm{NH}_{3}$ deposition rates over growing vegetation. Quantifying the overall emissions after slurry applications required the application of elaborate interpolations because of difficulties capturing the initial emissions during broadspreading of liquid manure. The emissions were also calculated with a mass balance method yielding similar fluxes. $\mathrm{NH}_{3}$ losses after slurry application expressed as percentage of emitted nitrogen versus applied total ammoniacal nitrogen (TAN) varied between 4 and 19\%, which is roughly a factor of three lower than the values for broadspreading of liquid manure in emission inventories. The comparatively low emission factors appear to be a consequence of the low dry matter content of the applied slurry and soil properties favouring ammonium adsorption.
\end{abstract}

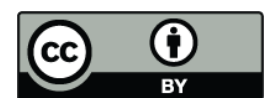

Correspondence to: C. Spirig (christoph.spirig@meteoswiss.ch)

\section{Introduction}

Ammonia $\left(\mathrm{NH}_{3}\right)$ is the most abundant alkaline substance in the atmosphere and has been recognised as a key player in processes leading to formation of particulate matter (e.g. Hayes et al., 1980; Kulmala et al., 2002; Erisman and Schaap, 2004; Vayenas et al., 2005; Yu, 2006) and eutrophication and acidification of ecosystems (Erisman et al., 2007). Because of these negative environmental impacts, the United Nations Economic Commission for Europe has included critical levels and loads for $\mathrm{NH}_{3}$ in the Convention on Long-Range Transboundary Air Pollution (UNECE, 1999). Recently it was recommended that these critical levels be further reduced (Cape et al., 2009) as new experiments have shown the occurrence of adverse effects on ecosystems even at concentrations below the current critical levels.

Agriculture represents the dominant $\mathrm{NH}_{3}$ source at global and national levels (Reidy et al., 2008; Spranger et al., 2009), with emissions occurring as part of animal husbandry, during manure storage and following the land spreading of organic wastes for fertilisation. Both agricultural and natural vegetation generally act as sinks for atmospheric $\mathrm{NH}_{3}$, as it is efficiently deposited on almost any kind of surface, particularly when they are wet. However, grasslands and agricultural crops can also be sources of $\mathrm{NH}_{3}$, e.g. after fertilisation or harvest, depending on the nitrogen status of vegetation (Sutton et al., 1993b; Mattsson et al., 2009). Given the prominent role of agriculture in controlling the atmospheric abundance of $\mathrm{NH}_{3}$, a better mechanistic understanding of its exchange over agricultural surfaces is required for accurately describing source-receptor relationships (Achermann and Bobbink, 2003).

Published by Copernicus Publications on behalf of the European Geosciences Union. 
Ammonia exchange over agricultural fields has been investigated in numerous studies (Sutton et al., 1993a, b; Herrmann et al., 2001; Spindler et al., 2001; Thompson and Meisinger, 2004; Walker et al., 2006) using micrometeorological techniques especially the aerodynamic gradient method (AGM) and more recently relaxed eddy accumulation (Hensen et al., 2009). The majority of instruments that have been deployed for $\mathrm{NH}_{3}$ flux measurements so far have used denuders for absorption of $\mathrm{NH}_{3}$ into acidic solution with subsequent wet chemical analysis. This concept has the advantage of adequately separating gas and aerosol phases, which is critical for precise $\mathrm{NH}_{3}$ measurements at ambient concentrations with typically similar amounts of aerosol ammonium being present. On the other hand, this approach strongly limits the measurement speed and the maintenance of the required low but precise liquid flows has proven to be labour-intensive in practice in the field. The challenging nature of flux measurements with such systems manifested itself in an extensive intercomparison campaign (Hensen et al., 2009; Milford et al., 2009), where good agreement between different instruments was only achieved with intensive maintenance and frequent calibrations. Although alternative analysers measuring $\mathrm{NH}_{3}$ directly in the gas phase have become available, either using mass spectroscopy (Nowak et al., 2002; Norman et al., 2007) or laser optical absorption methods (Longley et al., 2005), their applicability for routine micrometeorological flux measurements remains to be proven (Whitehead et al., 2008).

Because of these technical challenges it is not too surprising that only few long-term measurements of $\mathrm{NH}_{3}$ exchange at the ecosystem scale have been reported (Flechard and Fowler, 1998; Milford et al., 2001; Mosquera et al., 2001). In this study we report a 1.5-year dataset of semi-continuous $\mathrm{NH}_{3}$ gradient measurements for deriving exchange fluxes over grassland. The instrument based on a commercially available $\mathrm{NH}_{3}$ monitor has been operated since 2006 on an intensively managed meadow at Oensingen, Switzerland in the framework of the NitroEurope IP (www. nitroeurope.eu). A major goal of NitroEurope is the measurement of all major nitrogen inputs and outputs of selected ecosystems at the field scale. Ammann et al. (2009) calculated the nitrogen imports and exports of this grassland site and demonstrated that ammonia exchange and especially the emissions after slurry applications are expected to represent major terms of the nitrogen budget. Therefore it is important to measure ammonia emissions after fertilisation. While the AGM has successfully been used for quantifying $\mathrm{NH}_{3}$ exchange over non-fertilised vegetation, its use for measuring emissions immediately after slurry applications is problematic because some of its principal premises, such as the homogeneity of the surface, are violated (Génermont et al., 1998). In this paper we explore to what extent AGM measurements can be used to also quantify emissions after slurry applications and discuss methodical aspects of our gradient measurement system. The companion paper by Flechard et al. (2010) focuses on the annual $\mathrm{NH}_{3}$ budget and compensation point modelling for this site.

\section{Materials and methods}

\subsection{Site description}

Ammonia concentration and exchange flux measurements were made semi-continuously from July 2006 through October 2007 over managed permanent grassland at the Oensingen CarboEurope-IP (www.carboeurope.org) and NitroEurope-IP (www.nitroeurope.eu) experimental site in central Switzerland (longitude $7^{\circ} 44^{\prime} \mathrm{E}$, latitude $47^{\circ} 17^{\prime} \mathrm{N}$, elevation 450 ma.s.1.). The climate is temperate continental with mean annual temperature and rainfall of $9.5^{\circ} \mathrm{C}$ and $1200 \mathrm{~mm}$, respectively. The soil is classified as Eutri-Stagnic Cambisol (FAO, ISRIC and ISSS, 1998) developed on clayey alluvial deposits. Clay contents between $42 \%$ and $44 \%$ induce a total pore volume of $55 \%$ and a fine pore volume of $32 \%$ (permanent wilting point) as measured by means of the soil moisture release curve in the laboratory. The cation exchange capacity is $21-27 \mathrm{cmol} / \mathrm{kg}$.

The site consists of two adjacent rectangle grass fields of $146 \mathrm{~m} \times 52 \mathrm{~m}$ each, oriented SW to $\mathrm{NE}$ along the prevailing wind direction, as described in Ammann et al. (2007). The two fields were subject to contrasting management (intensive and extensive). The intensively managed grassland field of relevance for this study was covered by a permanent grass-clover mixture established in 2001, and was cut on average 4 times a year. It was fertilised in accordance with the standard agricultural practise in this part of the Swiss Plateau, typically twice annually with liquid cattle slurry and twice with ammonium nitrate pellets, amounting to about $200 \mathrm{kgNha}^{-1} \mathrm{yr}^{-1}$. However, during the time span of the measurements in 2006-2007, the field received exceptionally only slurry (3 times a year) and no mineral fertiliser, amounting to about $150 \mathrm{kgNha}^{-1} \mathrm{yr}^{-1}$. The applied slurry was a varying mixture of swine and cattle slurry. As the fraction of swine slurry was always smaller than $20 \%$, it is referred to as cattle slurry hereafter. Details on the applied manure for each event are given in Table 1.

\subsection{Ammonia concentration measurements}

\subsubsection{The AiRRmonia monitor}

The AiRRmonia $\mathrm{NH}_{3}$ concentration monitor (Mechatronics, Hoorn, The Netherlands; www.mechatronics.nl) was built and made commercially available on the back of a series of experimental instruments developed and tested at the Netherlands Energy Research Foundation (ECN, Petten, the Netherlands) over the course of the last 20 years (Erisman et al., 2001). In a similar way to its predecessors the AMANDA and AMOR (Wyers et al., 1993), the AiRRmonia 
Table 1. Slurry characteristics and air temperatures of the slurry applications in 2006 and 2007. Slurry analyses were carried out according to VDLUFA (2000) recommendations, air temperatures are $10 \mathrm{~h}$ averages after begin of spreading.

\begin{tabular}{lccccc}
\hline Date & $\begin{array}{c}\text { Application } \\
\mathrm{t} / \mathrm{ha}\end{array}$ & $\begin{array}{c}\text { TAN content } \\
\mathrm{g} / \mathrm{kg}\end{array}$ & $\mathrm{pH}$ & $\begin{array}{c}\text { Dry matter content } \\
(\%)\end{array}$ & $\begin{array}{c}\text { Air temperature } \\
\left({ }^{\circ} \mathrm{C}\right)\end{array}$ \\
\hline 13 Jul 2006 & 44 & 1.1 & 7.5 & 1.1 & 25.4 \\
27 Sep 2006 & 55 & 0.8 & 7.9 & 1.0 & 16.5 \\
30 Oct 2006 & 44 & 1.5 & 7.3 & 3.5 & 12.5 \\
3 Apr 2007 & 41 & 1.3 & 7.6 & 4.9 & 12.0 \\
13 Jul 2007 & 46 & 1.1 & 7.1 & 2.6 & 2.2 \\
24 Oct 2007 & 41 & 1.1 & 7.9 & 2.8 & 4.8 \\
\hline
\end{tabular}

continuously collects $\mathrm{NH}_{3}$ from the air by means of chemical scrubbing and performs on-line analysis of ammonium $\left(\mathrm{NH}_{4}^{+}\right)$in the liquid phase by means of conductivity measurements in a detector block (DB).

A fundamental difference of the AiRRmonia relative to the AMANDA, however, is the absence of a rotating wet annular denuder for scrubbing, which is replaced in the AiRRmonia by a stainless steel sampling block (SB) $(8 \mathrm{~cm} \times 15 \mathrm{~cm} \times 6 \mathrm{~cm})$. This comprises a gas-permeable teflon (PTFE) membrane, through which $\mathrm{NH}_{3}$ diffuses and is absorbed into a counter-flowing stream of a slightly acidic $\mathrm{NaHSO}_{4}$ stripping solution, with a nominal collection efficiency of $100 \%$. The air is drawn into the SB via a very short $(5-\mathrm{cm})$ polyethylene inlet tube $\left(1 / 16^{\prime \prime}\right.$ i.d.). As in the AMANDA denuder, the interference by $\mathrm{NH}_{4}^{+}$-containing aerosols is minimal (Otjes and Erisman, 1999). Piston pumps are used in the AiRRmonia to convey the stripping solution to the SB and thence to the DB; they are much less leak- and problem-prone than peristaltic pumps formerly used in the AMANDA. The AiRRmonia also uses a much lower sample air flow rate than the AMANDA $\left(11 \mathrm{~min}^{-1}\right.$ vs. $\left.301 \mathrm{~min}^{-1}\right)$ as well as a lower stripping solution flow rate $\left(0.11 \mathrm{ml} \mathrm{min}^{-1}\right.$ vs. $\left.1.3 \mathrm{ml} \mathrm{min}^{-1}\right)$. The AiRRmonia is thus less power-demanding, more robust, and is suited for long-term monitoring of atmospheric $\mathrm{NH}_{3}$ (Erisman et al., 2001) with a maintenance/calibration frequency of typically 1 week $^{-1}$ to 1 month $^{-1}$.

The measuring system is calibrated in the aqueous phase, using liquid standards of 0 (baseline), 50 and $500 \mu \mathrm{gNH}_{4}^{+} 1^{-1}$, which were freshly prepared every 2 months from a $1000 \mathrm{ppm}$ stock solution (Merck, Darmstadt, Germany). Assuming an operational air flow rate of $11 \mathrm{~min}^{-1}$ and a SB scrubbing efficiency of $100 \%$, these calibration solutions correspond to gas-phase concentrations of $0,5.2$ and $52 \mu \mathrm{gNH}_{3} \mathrm{~m}^{-3}$, respectively. A one time calibration with additional solutions of 125 and $5000 \mu \mathrm{gNH}_{4}^{+} 1^{-1}$ verified the validity of the three point calibration curve beyond the range of the routinely applied concentrations (the signals of both additional concentrations were within $5 \%$ of the three-point curve). The conductivity cells exhibit an upper detection limit of approximately $7500 \mu \mathrm{gNH}_{4}^{+} 1^{-1}$ corresponding to a gas phase concentration of $750 \mu \mathrm{gm}^{-3}$. The calibration procedure only describes the performance of the conductivity cell in the DB and does not address the issue of the SB scrubbing efficiency. However, a recent $\mathrm{NH}_{3}$ concentration intercomparison experiment (Norman et al., 2009) has shown a good agreement between the AiRRmonia, a GRAEGOR system (Thomas et al., 2009) and a PTRMS system (Norman et al., 2007), thus substantiating indirectly the assumption of stability of the SB scrubbing efficiency close to $100 \%$.

\subsubsection{Ammonia gradient measurements}

The AiRRmonia was originally designed for the purpose of long-term concentration monitoring at one reference height above ground (Erisman et al., 2001), and not for gradient ( $\geq 2$ heights) flux measurements. In order to measure a 2-point concentration profile above the grass canopy, two AiRRmonias in a modified configuration were mounted onto a little wagon on wheels (length $=1 \mathrm{~m}$; width $=1.5 \mathrm{~m}$; height $=2 \mathrm{~m}$ ). Both SBs were taken out of their AiRRmonia aluminium case and affixed to 2 extended horizontal arms at 2 heights, about $1 \mathrm{~m}$ away from the wagon, using extended lengths of PTFE tubing (1/32" i.d.) to transfer the stripping solution to- and from the SB. The two inlets were most of the time at heights of $0.36 \mathrm{~m}$ and $1.24 \mathrm{~m}$ above ground, though occasionally they were raised to heights of up to $0.53 \mathrm{~m}$ and $1.45 \mathrm{~m}$ above ground, as the grass canopy height increased in spring and summer. The wagon could be wheeled manually into and out of the field within $5 \mathrm{~min}$, without interrupting measurements (see Fig. 1).

Two 3-way PTFE solenoid valves were used to switch between the two inlet SBs (for sampling ambient air) on one hand, and the two DBs (for conductivity measurements) on the other hand. This setup ensured that 1) the concentrations at the two inlet heights were measured sequentially (15 min per height, i.e. $30 \mathrm{~min}$ for a gradient) by a common detector, which is essential for resolving the $\mathrm{NH}_{3}$ gradient, and 2) both DBs actually provided independent measurements of 


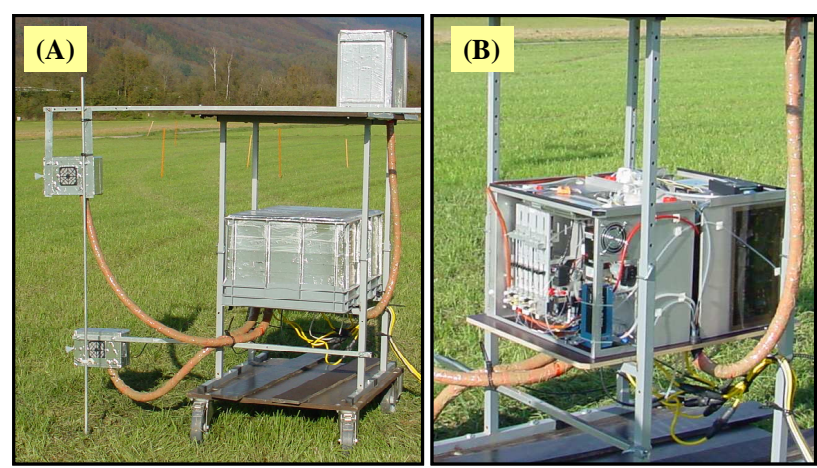

Fig. 1. The $\mathrm{NH}_{3}$ gradient measuring system: (A) the whole system with two inlet sampling blocks and, (B) the two AiRRmonia monitoring instruments on the analytical platform.

the same concentration difference between the two heights, albeit with a 15-min time shift. A delay loop with a specified length was built into the stripping solution transfer tubing between the second sampling block (SB2) and the solenoid valve to ensure that, even though the conductivity measurements for the liquid sample issuing from SB2 were made 15 min later than for $\mathrm{SB} 1$, the $\mathrm{NH}_{4}^{+}$concentrations measured in the stripping solution were representative of simultaneously scrubbed air parcels.

In addition, liquid flow rates were raised by $33 \%$ by increasing the syringe pump linear speeds from $12 \mathrm{mmmin}^{-1}$ in the default configuration up to $16 \mathrm{mmmin}^{-1}$. This allowed a faster response of the conductivity analyser for the purpose of gradient measurements. Figure 2 shows the time course of a 3-point calibration $\left(0,50\right.$ and $\left.500 \mu \mathrm{gNH}_{4}^{+} 1^{-1}\right)$ for both DBs, followed by two additional liquid standards (5000 then $125 \mu \mathrm{gNH}_{4}^{+} \mathrm{l}^{-1}$ ), allowing the e-folding response time $(\tau)$ of the conductivity cell to be calculated from fitted exponential decay curves for the successive concentration changes. The mean $\tau\left(1 / \mathrm{e}^{2}\right)$ values were 9.7 and $7.2 \mathrm{~min}$ for $\mathrm{DB} 1$ and DB2, respectively, with $\tau$ ranging from 4.3 to $14.8 \mathrm{~min}$, and tending to be longer for larger and downward step changes in concentrations.

During operational gradient monitoring, concentration differences between the bottom and top SBs were generally much lower than step changes during calibration, so that $\tau\left(1 / \mathrm{e}^{2}\right)$ could be expected to be lower, of the order of 5 to $7 \mathrm{~min}$. An example time series of continuous conductivity measurements (Fig. 3) with a 1-min time resolution during actual gradient measurements shows the 15 -min sequences of alternating bottom (SB1) and top (SB2) sample lines. The data show that the AiRRmonia in this altered configuration can detect, and resolve, half-hourly $\mathrm{NH}_{3}$ gradients thanks to a reduced time response. The 1-min measurements show short-term, wavelike fluctuations with a period of around 7 min, also visible in the calibration data on Fig. 2, and corresponding to a full up-and-down cycle of the syringe pump, possibly due to pressure effects on the detector.
Thus, to obtain representative mean values for each 15-min interval, the last $7 \mathrm{~min}$ were averaged (low-pass filter of pump-induced wave form) to yield mean liquid phase $\mathrm{NH}_{4}^{+}$ and gas-phase $\mathrm{NH}_{3}$ concentrations, allowing a stabilisation time of $8 \mathrm{~min}$ before averaging.

An estimate of the concentration detection limit was determined from the time series of the baseline $\left(0 \mathrm{\mu gNH}_{4}^{+} \mathrm{l}^{-1}\right)$ signal when the air pump was switched off. As $\mathrm{NH}_{3}$ concentrations are calculated routinely in our gradient configuration as 7-min averages, the detection limit was likewise computed as twice the standard deviation $(2 \sigma)$ of the 7-min mean values for the baseline signal. For the two AiRRmonias and conductivity cells used here, the detection limits were 0.07 and $0.08 \mu \mathrm{gNH}_{3} \mathrm{~m}^{-3}$, which is comparable to the $0.1 \mu \mathrm{gNH}_{3} \mathrm{~m}^{-3}$ given in Erisman et al. (2001). An accuracy of $10 \%$ was estimated as twice the standard deviation of calibration signals across all calibrations performed during the experiment (Norman et al., 2009); this is higher, though probably more realistic, than previously asserted in Erisman et al. (2001). In the following, we use the term MAGS (Mobile AiRRmonia Gradient System) for referring to the instrument for ammonia gradient measurements.

\subsubsection{Operation of the gradient system during slurry applications}

The farmer typically spread 3 to 4 tanks on the field, using a splash plate. The refilling and transport of the liquid manure trailer from the farm to the field took $15-20 \mathrm{~min}$. Hence it took between 1 and $1.5 \mathrm{~h}$ from the start of slurry spreading until the field was completely fertilised. The MAGS was operated just next to the field during manure spreading and was wheeled onto the field immediately after the first passage of the slurry tank. Concentrations at both heights rose instantaneously to several hundreds of $\mu \mathrm{gNH}_{3} \mathrm{~m}^{-3}$, sometimes exceeding the upper detection limit at the lower sampling height. The exceedance persisted from 1 to $4 \mathrm{~h}$, causing significant data gaps in the record of the lower height concentrations.

\subsection{Micrometeorological flux measurements and calculations}

\subsubsection{Aerodynamic gradient method}

Ammonia fluxes were measured using the aerodynamic gradient method (AGM) (Monteith and Unsworth, 1990; Sutton et al., 1993a), where the vertical turbulent exchange flux $F_{\chi}$ is proportional to the vertical gradient in concentration measured above the grass canopy with the coefficient of turbulent diffusion for $\mathrm{NH}_{3}$ or eddy diffusivity $K_{\chi}$, such that by Fick's law:

$F_{\chi}=-K_{\chi} \frac{\partial \chi}{\partial z}$ 


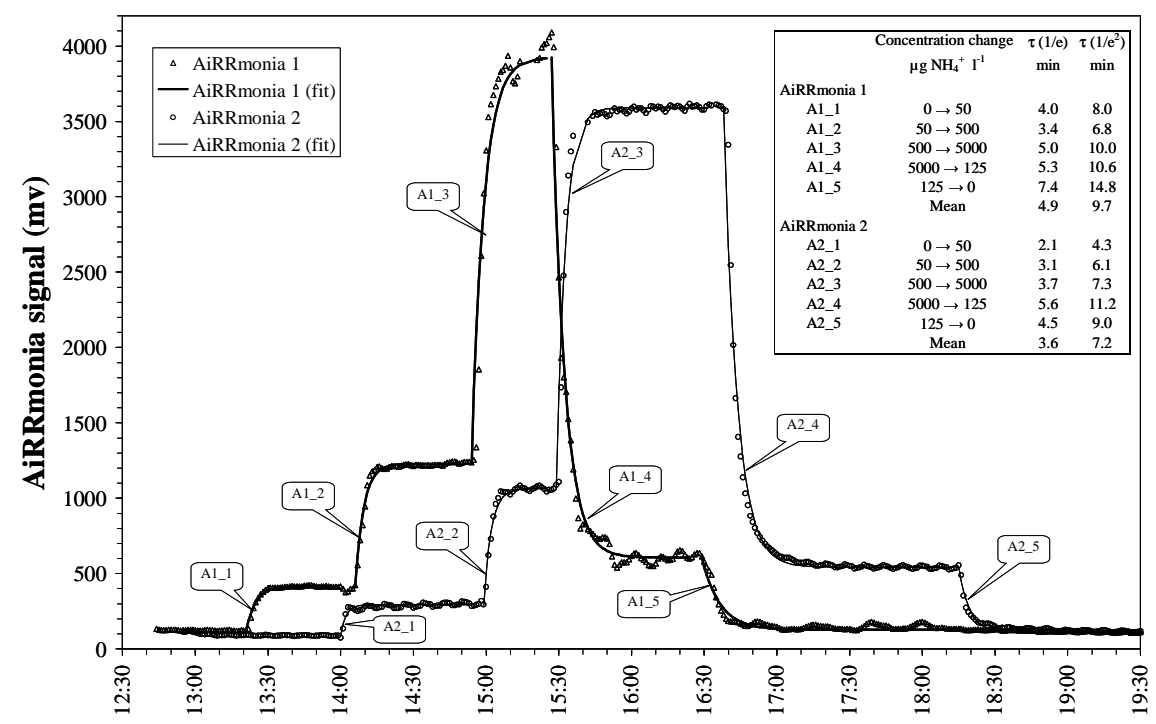

Fig. 2. Time course of liquid phase calibration of the two AiRRmonia conductivity cells. Measurements are 1-min averages. The listed values of the e-folding response times $(\tau)$ were determined by fitting the equation $S(t)=S_{0}+\left(S_{f}-S_{0}\right)\left(1-e^{-t / \tau}\right)$ to the measured signal $S$, where the indices " 0 " and " $\mathrm{f}$ " denote the initial and final concentrations, respectively.

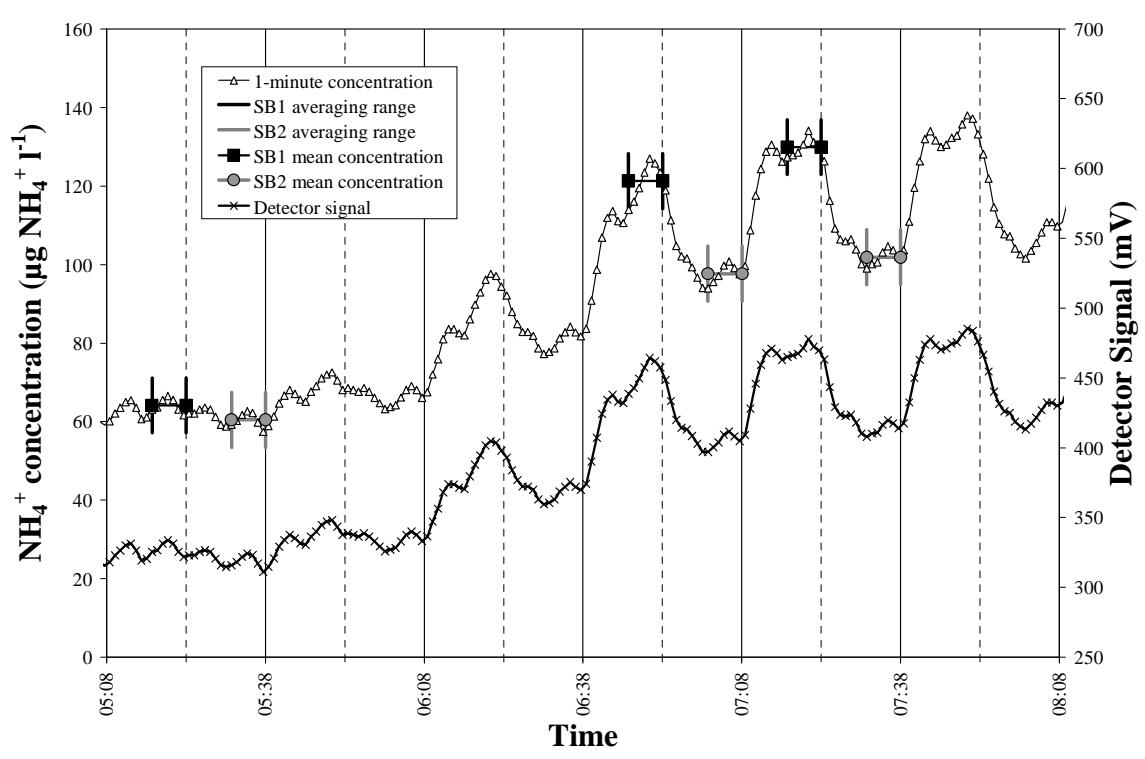

Fig. 3. Continuous conductivity and $\mathrm{NH}_{4}^{+}$measurements by the AiRRmonia in gradient configuration, providing 30-min mean gradient data using a common detector. The mean sampling block concentrations (SB1:bottom, and SB2:top) are calculated from the last 7 min of each 15-min interval.

where $\chi$ is $\mathrm{NH}_{3}$ concentration, $z$ is height above ground, and the minus sign by convention denotes deposition from the atmosphere. Since both $K_{\chi}$ and the vertical gradient of $\chi$ are variable with height, it is more convenient (Sutton et al., 1993a; Flechard and Fowler, 1998) to use an alternative form of Eq. (1) that expresses the flux as a function of height-independent friction velocity $u_{*}$ and the stability-corrected, log-linear vertical gradient of $\chi$ such that:
$F_{\chi}=-u_{*} \chi_{*}$

with

$\chi_{*}=k \frac{\partial \chi}{\partial\left(\ln (z-d)-\psi_{\mathrm{H}}\left(\frac{z-d}{L}\right)\right)}$

where $k$ is von Karman's constant $(0.41), d$ is the displacement height of the canopy, $L$ is the Obukhov length and $\psi_{\mathrm{H}}$ is the integrated stability function for heat and gases 
(Dyer and Hicks, 1970). The friction velocity and the Obukhov length in the present case were provided by a sonic anemometer (model HS, Gill instruments, Lymington, UK), which was implemented within the framework of concurrent eddy covariance measurements of $\mathrm{CO}_{2}$ and $\mathrm{H}_{2} \mathrm{O}$ exchange (Ammann et al., 2007). Both the sonic anemometer and the AiRRmonia profile system were located near the centre of the field for the duration of the experiment, so that fluxes could be measured for all wind directions, albeit with fetch values varying between 25 and $80 \mathrm{~m}$. For the dominant SW wind sector, the fetch was of the order of $70-80 \mathrm{~m}$. The sonic anemometer was affixed to a mast at a constant height of $1.2 \mathrm{~m}$ above ground, while $\mathrm{NH}_{3}$ concentrations were monitored at two heights as detailed above, from which $\chi_{*}$ was computed as a 2-point linear regression. Fluxes were calculated half-hourly.

Provided that 1) there is sufficient upwind fetch with homogeneous horizontal conditions and a fully developed turbulent layer above the grass surface; 2) there is no horizontal gradient in concentration $(d \chi / d x=0)$; 3) stationarity is respected $(d \chi / d t=0)$; and 4$)$ chemical reactions involving $\mathrm{NH}_{3}$ do not occur with sufficiently small time scales compared with the time scale of turbulent transfer; then there is no vertical flux divergence, which means that the flux measured at a reference height above the surface actually equates to the flux at the surface (Fowler and Duyzer, 1989).

Non-stationarity results in changes in the trace gas storage in the air column below the measurement point. If by convention a deposition flux is negative and an emission flux positive, an increase in air concentration leads to an underestimation of the true flux, while a decrease in air concentration results in the flux being overestimated. The vertical gradient in flux due to storage may be expressed as (Fowler and Duyzer, 1989):

$$
\frac{\partial F_{\chi}}{\partial z}=-\frac{\partial \chi}{\partial t}
$$

This storage correction was implemented routinely in the flux calculations, based on the time series of ambient $\mathrm{NH}_{3}$ concentration.

The Webb, Pearman and Leuning correction (Webb et al., 1980) was also routinely calculated for the latent heat component but was found to be mostly negligible, owing to the very low mixing ratio of $\mathrm{NH}_{3}$ compared with water vapour. The correction for sensible heat was not implemented as the air flows into the bottom and top air inlets of the AiRRmonias were mass-flow controlled, so that a vertical temperature gradient introduced no error in the measured $\mathrm{NH}_{3}$ flux.

Fluxes by the AGM method were calculated for times when both ammonia concentration and wind data were available and whenever the sonic anemometer measurements indicated sufficiently defined turbulence. Based on several years of experience with eddy covariance measurements at this site (Ammann et al., 2007), the following criteria for excluding stable and non-stationary conditions were applied. Data were only used if $(z-d) / L<10$ and the integral turbulence parameter $\sigma_{\mathrm{w}} / u_{*}$ (ratio of S.D. of vertical wind over friction velocity) evaluated at 3 min sub-intervals was within $60 \%$ of its corresponding half hour value (Foken and Wichura, 1996; Aubinet et al., 2000). For the period discussed here, this resulted in a $35 \%$ data rejection rate, mainly sorting out night time data (80\% of rejected data). After this selection, the aforementioned prerequisites for AGM flux measurements could be assumed to be largely met for measurements made in conditions of background $\mathrm{NH}_{3}$ exchange.

For cases when turbulence quality criteria were not met and no valid measurements of $u_{*}$ and sensible heat flux $(H)$ were available, $H$ was approximated from a multiple linear regression of the whole dataset of measured $H$ against net radiation, wind speed and air temperature. $u_{*}$ and $L$ were in turn calculated iteratively from the stability-corrected, loglinear wind profile (Monteith and Unsworth, 1990), and by setting the theoretical height of predicted zero wind speed (or roughness length) $z_{0}$ to $1 / 10$ of canopy height:

$$
U(z-d)=\frac{u_{*}}{k}\left[\ln \left(\frac{z-d}{z_{0}}\right)-\psi_{\mathrm{M}}\left(\frac{z-d}{L}\right)+\psi_{\mathrm{M}}\left(\frac{z_{0}}{L}\right)\right]
$$

\subsubsection{Footprint considerations and uncertainty assessment}

The application of slurry creates a situation with high emissions from the field itself, and low or reverse fluxes beyond. This results in a potentially severe flux divergence within the measurement footprint. This was addressed with an analytical footprint model (Kormann and Meixner, 2001), referred to as KM model hereafter. This model has been shown to produce plausible footprint estimates for $\mathrm{CO}_{2}$ eddy covariance measurements at the Oensingen site (Neftel et al., 2008). As investigated by Horst (1999), the flux footprint derived from gradient measurements at heights $z_{1}$ and $z_{2}$ corresponds to that of a single height eddy covariance flux measurement at the arithmetic and geometric mean of these heights for stable and unstable conditions, respectively. The fraction $(p \leq 1)$ of the fertilised field within the footprint of the gradient measurement was thus calculated by running the KM model for the respective heights depending on stability, wind speed and wind direction. For situations of slurry application, it is reasonable to assume zero $\mathrm{NH}_{3}$ emissions outside the fertilised field. The measured flux was then multiplied by $p^{-1}$ to correct for potential underestimation due to neighbouring fields within the footprint. During the spreading of manure (see Sect. 2.2.3), it was assumed that one third and two thirds of the field were covered with slurry during the first and the second half hour, respectively.

Following Eqs. (2) and (3), the uncertainty of fluxes $\left(\sigma_{F}\right)$ calculated by the AGM was assessed as

$\sigma_{\mathrm{F}}=\sqrt{\sigma_{u_{*}}^{2}+\sigma_{\chi}^{2}+\sigma_{\Psi}^{2}+\sigma_{\mathrm{FP}}^{2}}$, 
where $\sigma_{u_{*}}, \sigma_{\chi}, \sigma_{\Psi}, \sigma_{\mathrm{FP}}$ denote the relative uncertainties of the friction velocity, the concentration difference measurement, the integral stability function for heat and scalars, and the footprint correction, respectively. The relative uncertainty of $u_{*}$ was taken as two standard deviations of its variability in the corresponding three-minute subintervals, $15 \%$ was used for $\sigma_{\chi}$ (standard propagation of the $10 \%$ measurement uncertainty), and $\sigma_{\mathrm{FP}}$ was estimated as $0.3 \cdot(1-p)$, i.e. assuming the footprint model is capable of quantifying the influence of neighbouring fields with an accuracy of $30 \%$. Although $L$ and thus $\psi$ depend on both $u_{*}$ and heat flux $(H), \sigma_{\Psi}$ was estimated solely taking into account the error of $H$. This simplification is justified by the form of Eq. (6) implying independence of the error terms and taking into account $\sigma_{u_{*}}$ separately. The error of $H$ was determined in analogy to $\sigma_{u_{*}}$ from its variability in the sub-intervals, and was then propagated into $\psi$.

\subsubsection{Alternative flux calculation for emission peaks}

The mass balance method (MBM) (Denmead, 1995; Génermont et al., 1998), which has in the past been used extensively to measure $\mathrm{NH}_{3}$ emissions by applied slurry, was used as an alternative approach to estimate the fluxes following manure applications. Although the experimental setup at Oensingen had not been designed with the MBM in mind, an MBM-like approach was implemented as a supplement.

The mass balance was calculated as the amount of $\mathrm{NH}_{3}$ crossing a vertical plane up to the height of the internal boundary layer of the field $\left(z_{\mathrm{IBL}}\right)$, given by:

$F_{\chi}=1 / X \int_{z_{0}}^{z_{\mathrm{IBL}}} U(z)\left[\chi(z)-\chi_{\mathrm{bgd}}(z)\right] \partial z$

with $X$ denoting the distance along the main wind axis between the mast and the upwind edge of the field. $z_{\mathrm{IBL}}$ is parameterised as $0.334 \cdot z_{0}\left(X / z_{0}\right)^{0.875}$ (Itier and Perrier, 1976; Sommer et al., 2003), and $\chi_{\text {bgd }}$ is the background $\mathrm{NH}_{3}$ concentration at the upwind edge of the measurement field. Since there were no direct measurements of $\chi_{\text {bgd }}$, a constant value was assumed over time and vertically, set equal to the monthly median concentration measured at this site, which ranged from 1 to $5 \mu \mathrm{gNH}_{3} \mathrm{~m}^{-3}$. Log-linear profile shapes were assumed in order to recreate vertical profiles of wind speed $U(z-d)$ and concentration $\chi(z-d)$ through the internal boundary layer from the actual (measured) friction velocity and 2-point $\mathrm{NH}_{3}$ concentration gradient. The standard stability-corrected, log-linear relationships of $U(z-d)$ (Eq. 5) and $\chi(z-d)$ (Monteith and Unsworth, 1990; Sutton et al., 1993a) were applied:

$\chi(z-d)=\frac{\chi_{*}}{k}\left[\ln \left(\frac{z-d}{z_{\chi}}\right)-\psi_{\mathrm{H}}\left(\frac{z-d}{L}\right)+\psi_{\mathrm{H}}\left(\frac{z_{\chi}}{L}\right)\right]$

with $\psi_{\mathrm{H}}$ the integrated stability function for heat flux (Dyer and Hicks, 1970), and $z_{\chi}$ the nominal height above $d$ of predicted zero concentration. While the theoretical height above $d$ of predicted zero wind speed $\left(z_{0}^{\prime}\right)$ is easily derived from the knowledge of $u_{*}$ and $U$ measured at sonic height (Eq. 5), it is less straightforward for $z_{\chi}$, which is not defined for the emission case when $\mathrm{NH}_{3}$ concentration decreases with height. An equivalent function is thus used for $\mathrm{NH}_{3}$ instead of Eq. (8), which does not require $z_{\chi}$ explicitly:

$\chi(z-d)=\chi\left(z_{\text {int }}\right)+\frac{\chi_{*}}{k}\left[\ln (z-d)-\psi_{\mathrm{H}}\left(\frac{z-d}{L}\right)\right]$

where $\chi\left(z_{\text {int }}\right)$ and $\chi_{*} / k$ are the intercept and slope, respectively, of the linear regression of $\chi$ vs. $\left[\ln (z-d)-\psi_{\mathrm{H}}((z-d) / L)\right]$.

\section{Results}

\subsection{Performance of the MAGS instrument}

The MAGS was operated from early July 2006 through end of October 2007 during a total of 310 measuring days. The measurements covered six manure applications and 5 complete growth-cut cycles of the grassland. Operation was interrupted during winter (mid December 2006 until begin of March 2007) and for shorter periods in the second half of the year 2007.

Figure 4 compares concentrations and fluxes determined from the two detection units for the whole data set. The two detection units agreed well, considering that this is not actually a comparison of two measurements of the same gradients, but of gradients separated by $15 \mathrm{~min}$. Therefore, the half hourly concentrations and fluxes were calculated as averages of the two detection units, whenever both systems were operating, and if only one detection unit was running, its 15 -min value was taken as representative for the corresponding half hour. The configuration with two sampling blocks and effluent analysis by a common detector was essential to achieve a precision sufficient for gradient measurements, because the two detectors occasionally exhibited offsets larger than the detection limit. However, even in these cases the concentration differences between the two sampling units remained consistent.

In order to verify the equality of the $\mathrm{NH}_{3}$ scrubbing efficiencies and to identify the appropriate times to service the sampling units (exchanging Teflon membranes and cleaning), the two sampling blocks were periodically operated next to each other at the same height ("co-sampling"). The intercomparison of the concentrations during these side-by-side samplings following the weekly maintenance is shown in Fig. 5. The slope does not significantly deviate from one nor is the intercept significantly different from zero, confirming the equal performance of both absorption units. Furthermore, these side-by-side tests supported the detection limit of $0.1 \mathrm{\mu gm}^{-3}$ derived from measurements without air flow. 

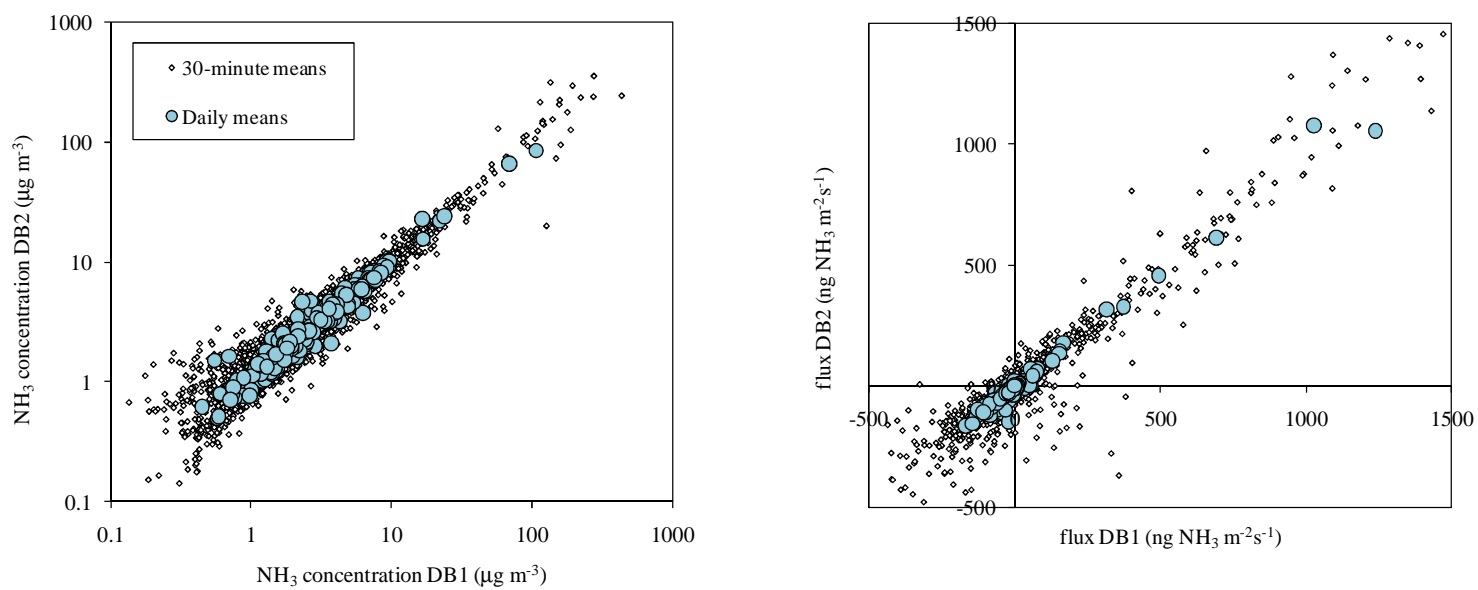

Fig. 4. Comparison of $\mathrm{NH}_{3}$ concentrations (left) and fluxes (right) measured by both AiRRmonia detection blocks DB1 and DB2.

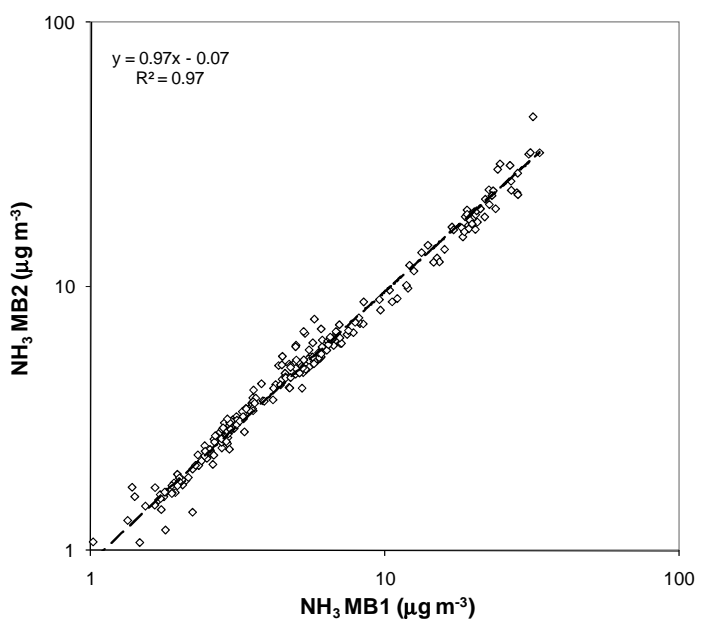

Fig. 5. Comparison of $\mathrm{NH}_{3}$ concentrations from both sampling blocks during side-by-side sampling.

Figure 6 illustrates the relative contributions of the different terms to the overall uncertainty of the $\mathrm{NH}_{3}$ flux measurements during and after a slurry application. Immediately after manure spreading (on 3 April 2007 at 13:00), the uncertainties related to turbulent transfer dominated, whereas the precision of the concentration measurement became limiting as concentrations declined to background levels, in this particular case already on the following day as a consequence of rain fall. The footprint correction contributed significantly to the overall uncertainty if the measurement fetch was insufficient during certain periods with wind directions perpendicular to the main field axis. During concentration levels close to background the median uncertainty of single (30-min) flux measurements was $30 \%$ overall, and $19 \%$ for daytime values only. In these background conditions, the precision of the flux measurement is dominated by the uncertainty of the concentration difference. The $2 \sigma$-detection limit of the concentration difference was $0.28 \mu \mathrm{gm}^{-3}$, assuming standard propagation of the above mentioned measurement precision. The typical daytime transfer velocity (ratio of flux to concentration difference) varied between 0.015 to 0.03 $\mathrm{ms}^{-1}$. Using the latter value and the $0.28 \mu \mathrm{gm}^{-3}$ detection limit translates into a flux of $8.4 \mathrm{ngNH}_{3} \mathrm{~m}^{-2} \mathrm{~s}^{-1}$ or a flux detection limit of about $10 \mathrm{ngNH}_{3} \mathrm{~m}^{-2} \mathrm{~s}^{-1}$.

\subsection{Concentration and flux measurements after slurry application}

With the first valid gradient measurements after slurry applications, fluxes of 25 to $70 \mu \mathrm{gNH}_{3} \mathrm{~m}^{-2} \mathrm{~s}^{-1}$ were observed. Figure 7 shows a typical time course of ammonia concentrations and fluxes during the first six days after manure spreading. After the initial emission burst, the influence of environmental conditions (rain, wind speed and irradiation) on the time course of ammonia fluxes can be seen, with an enhancing effect of higher wind speed and solar radiation, and attenuation by rain, respectively.

The application of the KM footprint model resulted in a scaling of individual, uncorrected AGM fluxes by up to a factor of 1.7 during wind directions perpendicular to the main field axis. The effect of the footprint adjustment on the sum of measured fluxes in the 5 days following slurry application was $34 \%$ on average (range of 14 to $59 \%$, see Table 2).

A comparison of the ammonia fluxes on the days of slurry application as calculated by AGM and MBM is presented in Fig. 8. The two approaches agreed better for the first three cases in 2006 than for the 2007 events. The situations in July 2007 and April 2007 were characterised by weak winds of varying and uncertain directions following the application of slurry. In these two cases, the differences between both calculation methods were most prominent at low wind speeds and considerable wind variations. The difference on 


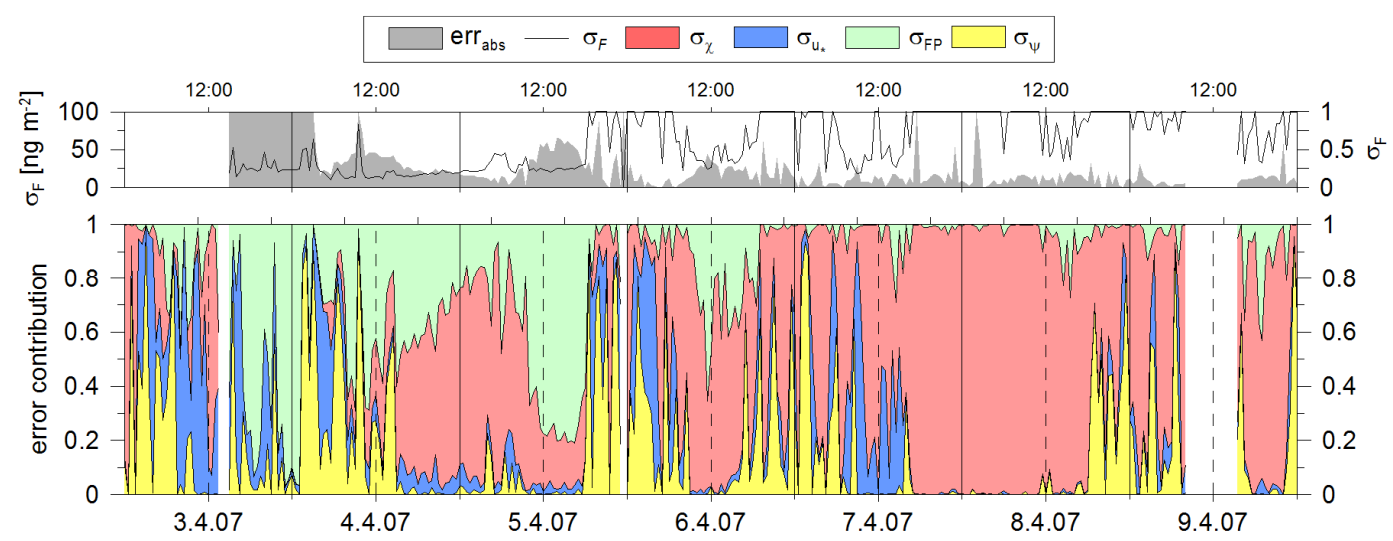

Fig. 6. Top: absolute and relative uncertainty of individual flux measurements (uncertainties clipped to axis maximum), and bottom: apportionment of the different error components.

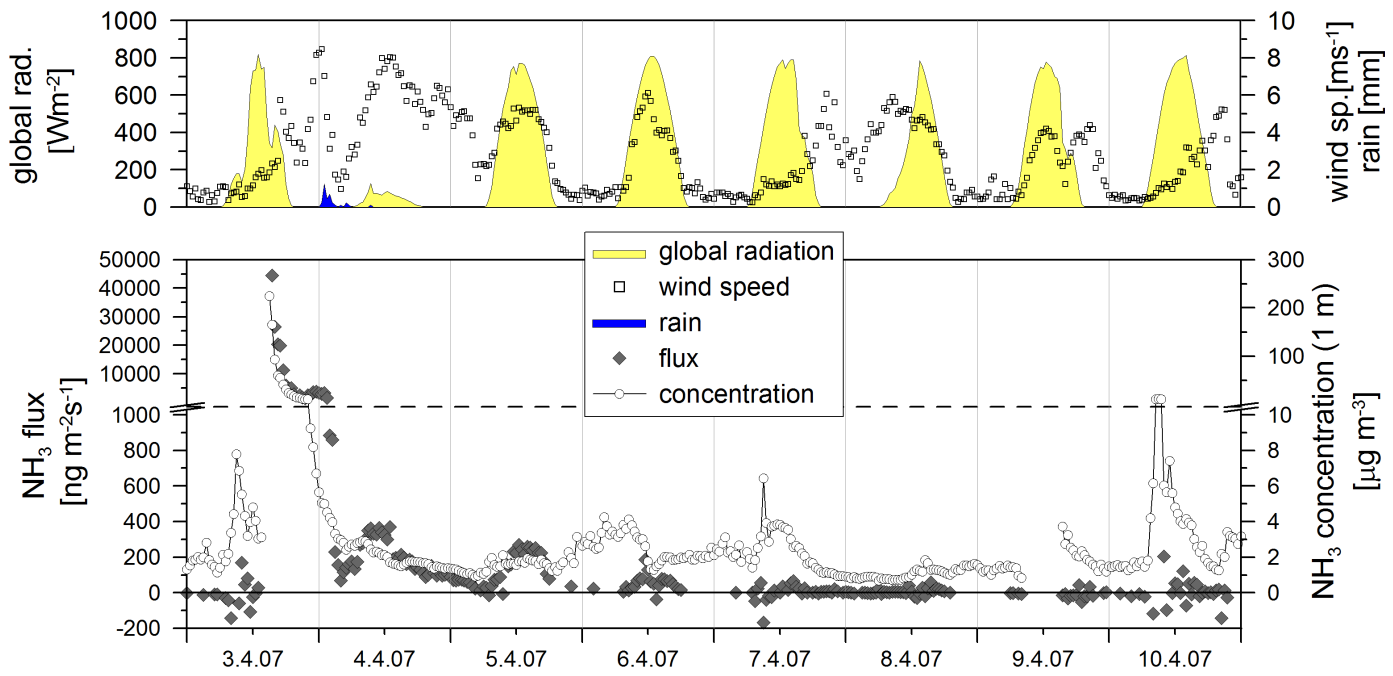

Fig. 7. Time series of of global radiation, wind speed, rainfall, ammonia concentrations and footprint-corrected fluxes after slurry application on 3.4.07. Note the ordinate breaks for visualising the dynamics both on the first and the following days.

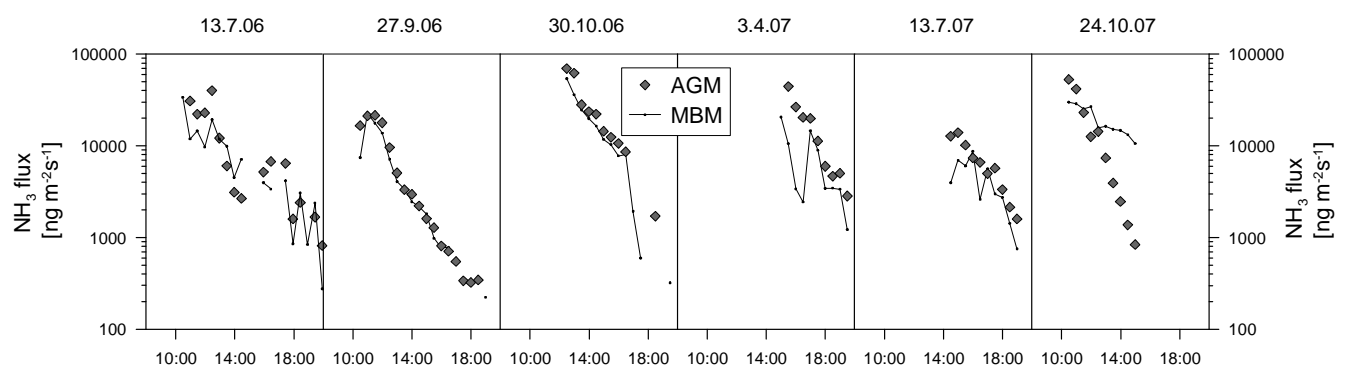

Fig. 8. Ammonia fluxes on the days of slurry application, comparison of footprint-corrected AGM fluxes and MBM results. 
Table 2. Cumulative $\mathrm{N}$ losses after slurry applications and footprint correction for the sum of valid measurements. The ranges of cumulative losses reflect the influence of lower and upper limit estimates of initial fluxes (see Sect. 3.3).

\begin{tabular}{lrrr}
\hline Date & $\begin{array}{r}\text { Cumulative losses } \\
\mathrm{kg} \mathrm{NH}_{3}-\mathrm{N} \mathrm{ha}^{-1}\end{array}$ & $\begin{array}{r}\text { Cumulative losses } \\
\text { as fraction of } \\
\text { applied TAN }\end{array}$ & $\begin{array}{r}\text { Footprint } \\
\text { correction }\end{array}$ \\
\hline 13 Jul 06 & $5.5-6.1$ & $11.6-13 \%$ & $29 \%$ \\
27 Sep 06 & $1.9-2.3$ & $4.2-5.2 \%$ & $45 \%$ \\
30 Oct 06 & 7.6 & $11.8 \%$ & $59 \%$ \\
3 Apr 07 & $4.5-5.7$ & $8.7-11 \%$ & $38 \%$ \\
13 Jul 07 & $5-9.1$ & $10.1-18.6 \%$ & $14 \%$ \\
24 Oct 07 & 3.3 & $7.3 \%$ & $16 \%$ \\
\hline
\end{tabular}

24 October 2007 looked more systematic. AGM and MBM fluxes followed each other closely during the first $2 \mathrm{~h}$ after slurry application, but while AGM fluxes fell rapidly in the afternoon, the MBM fluxes decreased only slightly. This day was characterised by rather strong and steady winds parallel to the field orientation and thus favourable conditions for micrometeorological flux measurements. MBM calculations using different background assumptions for this case showed that the fluxes were not sensitive to the inflow concentrations in the first $2.5 \mathrm{~h}$ ( 5 data points in Fig. 8), but were quite sensitive afterwards, yielding 30\% lower fluxes for an increase of the estimated ammonia inflow concentration from 2 to $6 \mu \mathrm{gm}^{-3}$.

\subsection{Estimates of initial emission fluxes not captured by measurements}

In four out of six slurry application events (July and October 2006, April and July 2007), the $\mathrm{NH}_{3}$ concentrations initially measured at the lower sampling height exceeded the detection range of the AiRRmonia monitors for 1 to $4 \mathrm{~h}$. Further occasional gaps in concentrations also occurred through instrumental failure of the MAGS. For these cases, and in order to produce a complete (or gap-filled) time series to calculate the cumulative emission, an empirical estimate of ammonia concentration at the surface $\chi\left(z_{0}^{\prime}\right)$ needed to be used as a predictor of the emission strength.

First, from the fluxes measured after the problematic initial phase and excluding the $1.5 \mathrm{~h}$ period of actual spreading (incomplete field slurry cover), the concentrations at the surface were derived by downward extrapolation of the $\log$-linear profile, using the concentrations at the reference height $z_{\text {ref }}(=1 \mathrm{~m}$ aboved) and footprint-adjusted fluxes $\left(F_{\chi, \text { cor }}\right)$, such that:

$\chi\left\{z_{0}^{\prime}\right\}=\chi\left\{z_{\text {ref }}\right\}+F_{\chi, \text { cor }}\left(R_{a}\left\{z_{\text {ref }}\right\}+R_{b}\right)$

$R_{a}$ and $R_{b}$ are the aerodynamic and viscous sublayer resistances and were calculated as described in Flechard et al. (2010). Ammonia concentrations at the upper sampling height were nearly always available and were linearly interpolated if missing.

The gas phase concentration $\chi\left(z_{0}^{\prime}\right)$ at the surface was then assumed to be in equilibrium with the emitting liquid surface, whose emission potential can be characterised by the $\left[\mathrm{NH}_{4}^{+}\right]$ to $\left[\mathrm{H}^{+}\right]$ratio $\left(\Gamma_{\text {surface }}\right)$ such that, assuming ideal solution and using Henry's law and dissociation constants (Bates and Pinching, 1950; Dasgupta and Dong, 1986):

$$
\begin{gathered}
K_{H}=56.04 \times \exp \left\{4092 \times\left(\frac{1}{T}-\frac{1}{298.15}\right)\right\} \\
\mathrm{Matm}^{-1}, T \text { in K }
\end{gathered}
$$

$$
K_{H}=5.67 \times 10^{-9} \times \exp \left\{6286 \times\left(\frac{1}{T}-\frac{1}{298.15}\right)\right\}
$$

$\mathrm{M}, T$ in $\mathrm{K}$

$$
\begin{gathered}
\Gamma_{\text {surface }}=\frac{\chi\left\{z_{0}^{\prime}\right\} \times 10^{-9}}{10^{4.1218-4507 / T\left\{z_{0}^{\prime}\right\}}} \\
\chi\left(z_{0}^{\prime}\right) \text { in ppband } T\left(z_{0}^{\prime}\right) \text { in } \mathrm{K}
\end{gathered}
$$

The $\Gamma_{\text {surface }}$ ratio thus describes the bulk emission potential of the canopy/soil/slurry layer system. For all manure applications in 2006 and 2007, the $\Gamma_{\text {surface }}$ ratios during the first week after slurry spreading could be roughly described by an exponential decay over time (Flechard et al., 2010). Given the dominance of the fluxes on the day of manure application, however, separate log linear regressions were applied for the first $10 \mathrm{~h}$ only (Fig. 9). The gaps in $\Gamma_{\text {surface }}$ between valid flux measurements were filled by a log linear regression of $\Gamma_{\text {surface }}$ versus elapsed time after slurry application. Figure 9 also includes the corresponding values of the slurry $\left(\Gamma_{\text {slurry }}\right)$ in each case at $t=0$, as obtained from using measured $\mathrm{pH}$ and ammonium contents (Table 1) in Eq. (13). For the slurry events in 6 July, 6 October, 7 April, and 7 July, $\Gamma_{\text {surface }}$ was interpolated between $\Gamma_{\text {slurry }}$ and the first "measured" $\Gamma_{\text {surface }}$ (Fig. 9) with both a lower and upper limit assumption. First the missing values were log-linearly interpolated (shown as empty symbols in Fig. 9). This represents a lower limit estimate, because it implicitly assumes a homogeneously fertilised field (at time $=0$ ), not taking into account the supply of fresh slurry during the first $1.5 \mathrm{~h}$ through the sequential spreading. As an upper limit estimate, the initial surface concentrations were calculated by repeating the initial $\Gamma_{\text {slurry value until the }}$ first experimental $\chi\left(z_{0}^{\prime}\right)$ was available, i.e. by taking $\chi\left(z_{0}^{\prime}\right)$ over pure slurry and assuming that the slurry layer remains unadulterated (no evaporation, no percolating through soil) for the entire gap period.

A rough validity check of these interpolations was made using the two events (September 2006 and October 2007) which did not suffer from the upper detection limit exceedance problem. This was done by omitting the 
13.7.2006

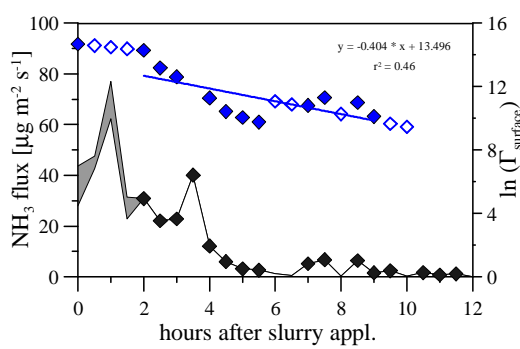

3.4.2007

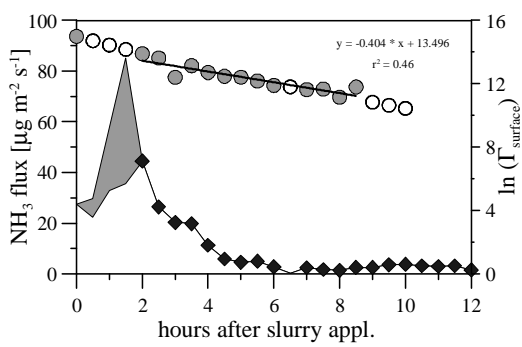

29.6.2006

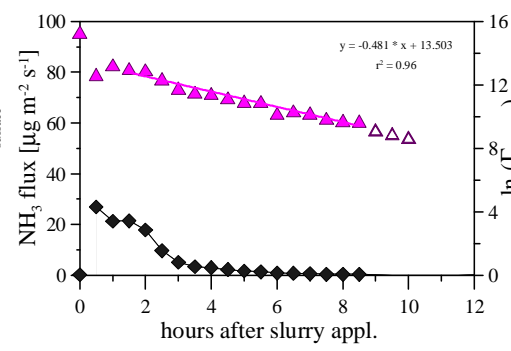

13.7.2007

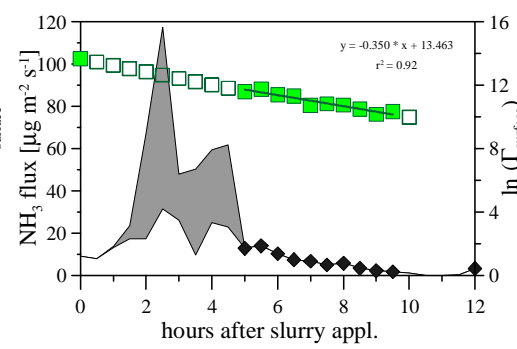

30.10 .2006

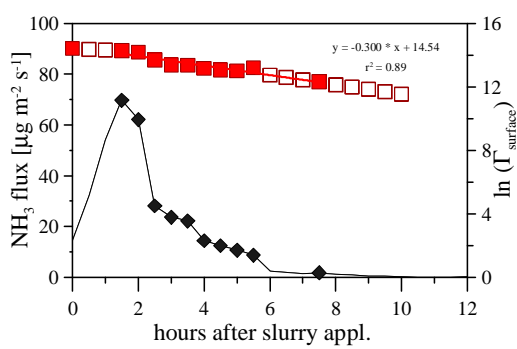

24.10.2007

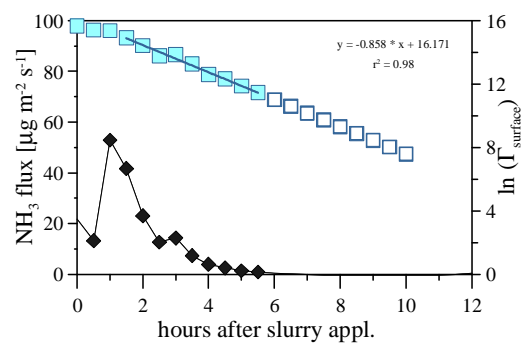

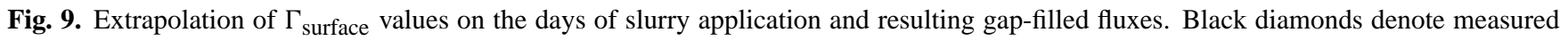
fluxes and coloured filled symbols are $\Gamma$ ratios as derived from slurry analyses $(t=0)$ and from flux measurements $(t>0)$. Empty symbols are $\Gamma$ values obtained from interpolations, and lines show the gap-filled fluxes, whereas the grey ranges indicate the effects of lower and upper limit assumptions during the first hours.

first $2 \mathrm{~h}$ of measurements and calculating upper and lower limits using the same procedure. The resulting interpolated fluxes accumulated to values smaller (15-19\%) and larger $(10-54 \%)$ than the sum of measured fluxes, when using the lower and upper limit assumption, respectively.

\subsection{Cumulative $\mathrm{NH}_{3}$ losses after slurry applications}

Table 2 summarises cumulative $\mathrm{NH}_{3}$ losses for the six slurry applications during 2006 and 2007. The losses expressed as percentage of emitted $\mathrm{NH}_{3}-\mathrm{N}$ vs. applied total ammoniacal nitrogen (TAN) varied between 4 and 19\%. The losses are expressed either as a single number for the September 2006 and October 2007 events, or as a range for the other four events when the lack of initial measured fluxes introduced additional uncertainty in the overall losses. For the purpose of annual budget calculations (Flechard et al., 2010), the averages of the upper and lower ranges were used.

The uncertainty resulting from flux measurement errors was estimated by calculating the cumulative uncertainty over all valid measurements assuming Gaussian propagation of individual flux uncertainties (calculated as described in Sect. 2.3.3). These non-systematic errors accumulated to $10-15 \%$ of the overall losses. Comparing them with the systematic uncertainties indicated by the range between upper and lower estimates of initial fluxes revealed that the overall uncertainty is clearly dominated by the problem of quantifying the fluxes at the very beginning after slurry spreading.

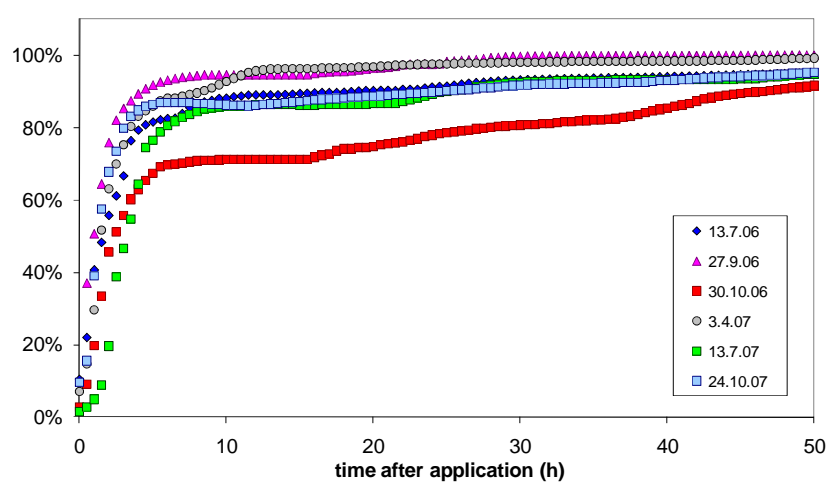

Fig. 10. Time course of cumulative ammonia emissions relative to total losses for six slurry applications.

The time course of the emissions after the slurry applications is illustrated in Fig. 10. Except for the fertilising in October 2006, $80 \%$ of the total emitted ammonia was volatilised on the day of application and $90 \%$ during the first two days. The outstanding October 2006 event was characterised by almost $100 \%$ relative humidity during the first two days and a humidity drop in connection with an increase in wind speed on the third day, which may explain the different emission dynamics in comparison to the other cases. 


\section{Discussion}

\subsection{Methodological aspects}

The MAGS proved to be a reliable system for long term measurements of $\mathrm{NH}_{3}$ exchange over a managed grassland site and required servicing and calibration at weekly to bi-weekly intervals. While other instruments for measurements of ammonia gradients like the AMANDA, GRAHAM, or GRAEGOR (Wyers et al., 1993; Wichink Kruit et al., 2007; Thomas et al., 2009) have better accuracy and detection limits, MAGS is advantageous in terms of long term deployment.

The mobility of the MAGS was helpful for measuring $\mathrm{NH}_{3}$ exchange over this field with regular management activities, as it allowed a quick removal and re-installation after machines had passed, even without interrupting the measurements. Although this helped to minimise the idling of the instrument after slurry applications, measuring the first few hours after the spreading still proved to be difficult, not to mention emissions during spreading itself. First there was the instrument-specific restriction by the upper detection limit of the conductivity cell. This limitation might be avoided in future by increasing the ratio of liquid to air flow during the first few hours after slurry spreading. A second problem is the changing fetch during the slurry application due to the time necessary for spreading 3 to 4 tank volumes on the field (typically $1.5 \mathrm{~h}$ ). This challenge is common to any type of vertical flux measurement method, but it may be partly overcome if instruments capable of quantifying vertical fluxes on shorter time scales become available.

The general agreement of the footprint-corrected AGM and the MBM technique for measuring $\mathrm{NH}_{3}$ losses after slurry spreading confirmed the consistency of the vertical and horizontal flux calculation concepts. While the MBM showed similar results most of the time, its application became problematic in situations with unsteady and low wind speeds. While a varying wind regime may also compromise the AGM technique, it is still tolerant as long as the sampling point is in the middle of the field with similar fetch lengths around the windrose. MBM, on the other hand, only considers the upwind distance of the (rectangular) field, which varies dramatically with even slight wind shifts if the direction is not parallel to the main field axis. The field boundary layer height is not well defined under these circumstances and apparently resulted in an underestimate by the MBM fluxes. In addition, the MBM requires knowledge of the background concentration, which can be difficult to estimate or to measure under certain situations. In the October 2007 case, the differences between AGM and MGM started to differ exactly at the time when the MGM results became sensitive to the assumption of inflow concentrations. It indicates that the upwind concentration was higher in this case than the assumed monthly median of $1.5 \mu \mathrm{gm}^{-3}$, and hence caused the MBM approach to overestimate the fluxes. The missing background measurements prevent a definitive interpretation, but an upwind concentration of $10 \mu \mathrm{gm}^{-3}$ during a few hours is certainly possible in this area of intensive agriculture. The Oensingen field site is rather demanding in this respect due to the patchy nature and the small field sizes of the agricultural landscape, in combination with often thermally induced winds of unsteady character. In such a case, MBM flux measurements need background concentrations to be monitored at least at half hourly intervals.

\subsection{Ammonia losses after slurry application}

Despite the uncertainties in the cumulative $\mathrm{N}$ losses determined here, it is clear that they were considerably lower than expected from typical emission factors currently used in emission inventories for spreading by splash plate. As part of the ALFAM (Ammonia Losses from Field-Applied Manure, www.alfam.dk) project, a comprehensive data base of emission measurements following manure application was collected and Søgaard et al. (2002) derived a parameterisation scheme including slurry and environmental variables for estimating ammonia emissions. The ALFAM model predicted losses in the range of $34-49 \%$ of applied ammoniacal nitrogen for the cases described here. Similarly, by applying a model based on experiments in Switzerland (Menzi et al., 1998), losses of 23-59\% were calculated. Overall, measured losses (mean of upper and lower limit estimates) were lower than model estimates by roughly a factor of three to four.

The limited number of slurry applications at a single experimental site recorded here precludes a thorough statistical analysis of the reasons for model-measurement differences. It is still noteworthy that a good correlation $\left(r^{2}\right.$ of 0.87$)$ was found between measured emissions and those predicted by the Menzi et al. parameterisation, but not between measurements and ALFAM results ( $r^{2}$ of 0.30$)$. The dominating environmental parameter in the Menzi et al. model is water vapour saturation deficit (WSD), which is not included in ALFAM, indicating that this variable was also of relevance for the emissions determined here. The manure application with the measured loss of only $4 \%$ in September 2006 also exhibited the lowest emissions in the Menzi et al. (22\%) and in the ALFAM (34\%) model calculations. It was not only characterised by the lowest WSD, but also by lowest slurry dry matter and nitrogen content among all events described here. The rather thin slurry may have favoured a faster penetration into the soil and therefore limited evaporation. It has been found by numerous previous studies that low dry matter content reduces ammonia losses (e.g. Pain et al., 1989; Vandre et al., 1997; Misselbrook et al., 2005b), and there are several reports on $\mathrm{NH}_{3}$ losses after slurry spreading by splash plates with emission factors lower than 20\% (Braschkat et al., 1997; Misselbrook et al., 2005a; Rochette et al., 2008) or even 10\% (Misselbrook et al., 2004) 
of applied TAN. Most of these low emission observations were associated with spreading of pig slurry (partly diluted) with low dry matter contents, albeit of similar magnitude as the manure applied here. The average dry matter content of the slurries spread in Oensingen was somewhat lower than that of the data used for creating the ALFAM and the Menzi et al. model, but this could only explain part of the lower emissions.

It should also be considered that the field size has an influence on the magnitude of emissions. As previously demonstrated (Génermont and Cellier, 1997; Sommer et al., 2003), emissions from a large field will be much smaller than from a small plot for otherwise identical conditions, because volatilisation is driven by the surface-air concentration difference, which decreases from the upwind edge of a freshly fertilised field. The experimental database for the development of emission models mainly consists of measurements over smaller plots, as records from large fields are barely available. It can therefore not be excluded that current emission factors derived from these models tend to overestimate $\mathrm{NH}_{3}$ volatilisation if applied to typical agricultural field sizes.

The mentioned empirical emission models do not include the influence of soil characteristics on ammonia volatilisation. High porosity and high cation exchange capacity (CEC) tend to limit $\mathrm{NH}_{3}$ losses after slurry application due to fast slurry infiltration and adsorption of ammonium to exchange sites, respectively (Sommer and Hutchings, 2001; Sommer et al., 2003). The CEC of more than $20 \mathrm{cmol} / \mathrm{kg}$ at this site effects a high capacity for ammonium adsorption. Ammonium adsortpion to the cation exchange sites in the topsoil will decrease ammonia concentrations at the surface and thus reduce ammonia emissions. The effect decreases with increasing amounts of TAN applied, as the soil may become saturated (Sommer et al., 2003). But given the doses applied here (on average $45 \mathrm{~kg} \mathrm{ha}^{-1}$ ) and the high adsorption capacity of the soil, the fixation capacity was far from being saturated. In summary, it is plausible that the soil characteristics at the Oensingen site conduced to low ammonia volatilisation rates, but this needs to be further investigated by additional measurements of soil properties before and after future manure applications.

\section{Conclusions}

The MAGS was suitable for measuring ammonia exchange fluxes over a managed grassland site at $15-30 \mathrm{~min}$ time resolution during two consecutive years. The setup with two sampling units connected to a common detector proved to be critical for achieving a performance sufficient for resolving concentration gradients not only after slurry applications but also during background exchange.

Measured ammonia fluxes after 6 cattle slurry spreading events (using a splash plate) were relatively low and resulted in total $\mathrm{N}$ losses of the order of 4-20\% of applied TAN. The low emissions appear to be a consequence of favourable properties of both the applied slurry and the soil. Further measurements including soil analyses immediately after slurry application are necessary to confirm the influence of soil properties on the emissions.

Given the problems related to the inhomogeneous and changing fetch during slurry application, the AGM technique has limitations for measuring the emissions during manure spreading. Further development of fast ammonia sensors may allow flux measurements at shorter time scales using the eddy covariance technique, but may only partly overcome these complications inherent in any vertical flux measurement method. Initial fluxes are accessible to measurement with mass balance concepts in combination with remote sensing techniques (Gaertner et al., 2008), but they still depend on steady wind conditions and knowledge of the inflow concentrations, which limits their applicability in certain situations. Ongoing projects at the Oensingen site aim to intercompare different vertical and horizontal flux approaches for measuring ammonia emissions after slurry applications at the field scale.

There are hardly any records available on measurements of ammonia losses after slurry spreading on whole agricultural fields, as most studies have looked at emissions from plots of a few tens of meters and in wind tunnels. The emissions of current inventories are therefore likely to reflect this predominance of smaller plot experiments in the underlying data base. As $\mathrm{NH}_{3}$ emissions from large fields are smaller than those from small plots under otherwise identical conditions, emission inventories might overestimate the slurry spreading emissions. If this is indeed the case, the strategies for ammonia mitigation merit reconsideration. Although such a bias in the inventories would not affect the relative influence of different manure application techniques or climatic conditions on losses during fertilisation, the benefit of investments into low emission spreading techniques would be overestimated in comparison to measures aiming at reducing emissions of animal housings or storage facilities. As a consequence, there is a clear need for more investigations on ammonia volatilisation after slurry spreading at the field scale to validate current numbers in emission inventories.

Acknowledgements. This work was part of the EU projects CarboEurope and NitroEurope (Contract 017841), funded under the EC 5th and 6th Framework Programme for Research and Technological Development. We thank C. Hüglin of EMPA Materials, Science \& Technology $(\mathrm{CH})$ for providing the two AiRRmonia monitors. R. Siegwolf of The Paul Scherrer Institute (CH) kindly lent us a sonic anemometer for several months after ours was destroyed in a hail storm. Finally we would like to acknowledge the continuous support of W. Ingold and his family at the Oensingen site.

Edited by: F. X. Meixner 


\section{References}

Achermann, B. and Bobbink, R.: Empirical critical loads for Nitrogen (Report of UNECE Expert Workshop, Berne 11-13 November 2002), SAEFL, Bern, Switzerland, 2003.

Ammann, C., Flechard, C. R., Leifeld, J., Neftel, A., and Fuhrer, J.: The carbon budget of newly established temperate grassland depends on management intensity, Agr. Ecosyst. Environ., 121, 5-20, 2007.

Ammann, C., Spirig, C., Leifeld, J., and Neftel, A.: Assessment of the nitrogen and carbon budget of two managed temperate grassland fields, Agr. Ecosyst. Environ.,133, 150-162, 2009.

Aubinet, M., Grelle, A., Ibrom, A., Rannik, U., Moncrieff, J., Foken, T., Kowalski, A. S., Martin, P. H., Berbigier, P., Bernhofer, C., Clement, R., Elbers, J., Granier, A., Grunwald, T., Morgenstern, K., Pilegaard, K., Rebmann, C., Snijders, W., Valentini, R., and Vesala, T.: Estimates of the annual net carbon and water exchange of forests: The EUROFLUX methodology, Adv. Ecol. Res., 30, 113-175, 2000.

Bates, R. G. and Pinching, G. D.: Dissociation constant of aqueous ammonia at 0 to 50-degrees from EMF studies of the ammonium salt of a weak acid, J. Am. Chem. Soc., 72, 1393-1396, 1950.

Braschkat, J., Mannheim, T., and Marschner, H.: Estimation of ammonia losses after application of liquid cattle manure on grassland, Z. Pflanz. Bodenkunde, 160, 117-123, 1997.

Cape, J. N., van der Eerden, L., Fangmeier, A., Ayres, J., Bareham, S., Bobbing, R., Branguinho, C., Crittenden, P., Cruz, C., Dias, T., Leith, I. D., Martins-Loucão, M. A., Pitcairn, C., Sheppard, L., Spranger, T., Sutton, M. A., van Dijk, N., and Wolseley, P.: Critical Levels for Ammonia, in: Atmospheric Ammonia, edited by: Sutton, M. A., Reis, S., and Baker, S. M. H., 375-382, Springer, Dordrecht, 2009.

Dasgupta, P. K. and Dong, S.: Solubility of ammonia in liquid water and generation of trace levels of standard gaseous ammonia, Atmos. Environ., 20, 565-570, 1986.

Denmead, O. T.: Novel meteorological methods for measuring trace gas fluxes, Philos. T. Roy. Soc. A, 351, 383-396, 1995.

Dyer, A. and Hicks, B.: Flux-gradient relationships in constant flux layer, Q. J. Roy. Meteor. Soc., 98, 206-212, 1970.

Erisman, J. W., Otjes, R., Hensen, A., Jongejan, P., van den Bulk, P., Khlystov, A., Mols, H., and Slanina, S.: Instrument development and application in studies and monitoring of ambient ammonia, Atmos. Environ., 35, 1913-1922, 2001.

Erisman, J. W. and Schaap, M.: The need for ammonia abatement with respect to secondary PM reductions in Europe, Environ. Pollut., 129, 159-163, 2004.

Erisman, J. W., Bleeker, A., Galloway, J., and Sutton, M. A.: Reduced nitrogen in ecology and the environment, Environ. Pollut., 150, 140-149, 2007.

Flechard, C. R., Spirig, C., Neftel, A., and Ammann, C.: The annual ammonia budget of fertilised cut grassland - Part 2: Seasonal variations and compensation point modeling, Biogeosciences, 7 , 537-556, 2010, http://www.biogeosciences.net/7/537/2010/.

Flechard, C. R. and Fowler, D.: Atmospheric ammonia at a moorland site. II: Long-term surface-atmosphere micrometeorological flux measurements, Q. J. Roy. Meteor. Soc., 124, 759-791, 1998.

Foken, T. and Wichura, B.: Tools for quality assessment of surface-based flux measurements, Agr. Forest Meteorol., 78, 83-105, 1996.
Fowler, D. and Duyzer, J. H.: Micrometeorological Techniques for the Measurement of Trace Gas-Exchange, Dahlem Workshop on Exchange of Trace Gases between Terrestrial Ecosystems and the Atmosphere, Berlin, Germany, ISI:A1989BU45V00013, 189-207, 1989.

Gaertner, A., Hirschberger, R., and Kotzian, F.: Estimation of diffuse ammonia emissions during and after slurry spreading, Gefahrstoffe - Reinhaltung der Luft, 68, 149-155, 2008.

Génermont, S. and Cellier, P.: A mechanistic model for estimating ammonia volatilization from slurry applied to bare soil, Agr. Forest Meteorol., 88, 145-167, 1997.

Génermont, S., Cellier, P., Flura, D., Morvan, T., and Laville, P.: Measuring ammonia fluxes after slurry spreading under actual field conditions, Atmos. Environ., 32, 279-284, 1998.

Hayes, D., Snetsinger, K., Ferry, G., Oberbeck, V., et al.: Reactivity of stratospheric aerosols to small amounts of ammonia in the laboratory environment, Geophys. Res. Lett., 7, 974-976, 1980.

Hensen, A., Nemitz, E., Flynn, M. J., Blatter, A., Jones, S. K., Sørensen, L. L., Hensen, B., Pryor, S. C., Jensen, B., Otjes, R. P., Cobussen, J., Loubet, B., Erisman, J. W., Gallagher, M. W., Neftel, A., and Sutton, M. A.: Inter-comparison of ammonia fluxes obtained using the Relaxed Eddy Accumulation technique, Biogeosciences, 6, 2575-2588, 2009, http://www.biogeosciences.net/6/2575/2009/.

Herrmann, B., Jones, S. K., Fuhrer, J., Feller, U., and Neftel, A.: N budget and $\mathrm{NH}_{3}$ exchange of a grass/clover crop at two levels of N application, Plant Soil, 235, 243-252, 2001.

Horst, T. W.: The footprint for estimation of atmosphere-surface exchange fluxes by profile techniques, Bound.-Lay. Meteorol., 90, 171-188, 1999.

Itier, B. and Perrier, A.: Analytical study of advection. 1. Advection with respect to relation with temperature, concentration and humidity, Ann. Agron., 27, 111-140, 1976.

Kormann, R. and Meixner, F. X.: An analytical footprint model for non-neutral stratification, Bound.-Lay. Meteorol., 99, 207-224, 2001.

Kulmala, M., Korhonen, P., Napari, I., Karlsson, A., Berresheim, H., and O'Dowd, C. D.: Aerosol formation during PARFORCE: Ternary nucleation of $\mathrm{H}_{2} \mathrm{SO}_{4}$, $\mathrm{NH}_{3}$, and $\mathrm{H}_{2} \mathrm{O}$, J. Geophys. Res.-Atmos., 107, 8111, doi:10.1029/2001JD000900, 2002.

Longley, I. D., Whitehead, J. D., Coe, H., and Gallagher, M. W.: Winter and summer ammonia emissions in the City of Manchester, UK, related to traffic and background sources measured using an aerodyne quantum cascade-TDLAS, 13th International Conference on Modelling, Monitoring and Management of Air Pollution, Cordoba, SPAIN, ISI:000230300700028, 261-268, 2005.

Mattsson, M., Herrmann, B., David, M., Loubet, B., Riedo, M., Theobald, M. R., Sutton, M. A., Bruhn, D., Neftel, A., and Schjoerring, J. K.: Temporal variability in bioassays of the stomatal ammonia compensation point in relation to plant and soil nitrogen parameters in intensively managed grassland, Biogeosciences, 6, 171-179, 2009, http://www.biogeosciences.net/6/171/2009/.

Menzi, H., Katz, P. E., Fahrni, M., Neftel, A., and Frick, R.: A simple empirical model based on regression analysis to estimate ammonia emissions after manure application, Atmos. Environ., 32, 301-307, 1998. 
Milford, C., Theobald, M. R., Nemitz, E., and Sutton, M. A.: Dynamics of ammonia exchange in response to cutting and fertilising in an intensively-managed grassland, Water Air Soil Pollut., 1, 167-176, 2001.

Milford, C., Theobald, M. R., Nemitz, E., Hargreaves, K. J., Horvath, L., Raso, J., Dämmgen, U., Neftel, A., Jones, S. K., Hensen, A., Loubet, B., Cellier, P., and Sutton, M. A.: Ammonia fluxes in relation to cutting and fertilization of an intensively managed grassland derived from an inter-comparison of gradient measurements, Biogeosciences, 6, 819-834, 2009,

http://www.biogeosciences.net/6/819/2009/.

Misselbrook, T. H., Smith, K. A., Jackson, D. R., and Gilhespy, S. L.: Ammonia emissions from irrigation of dilute pig slurries, Biosyst. Eng., 89, 473-484, doi:10.1016/j.biosystemseng.2004.08.015, 2004.

Misselbrook, T. H., Nicholson, F. A., and Chambers, B. J.: Predicting ammonia losses following the application of livestock manure to land, Bioresource Technol., 96, 159-168, doi:10.1016/j.biotech.2004.05.004, 2005a.

Misselbrook, T. H., Nicholson, F. A., Chambers, B. J., and Johnson, R. A.: Measuring ammonia emissions from land applied manure: an intercomparison of commonly used samplers and techniques, Environ. Pollut., 135, 389-397, 2005 b.

Monteith, J. and Unsworth, M.: Principles of Environmental Physics, 2nd edition, Edward Arnold, London, 291 pp., 1990.

Mosquera, J., Hensen, A., van den Bulk, W. C. M., Vermeulen, A. T., and Erisman, J. W.: Long term $\mathrm{NH}_{3}$ flux measurements above grasslands in the Netherlands, Water Air Soil Pollut., 1, 203-212, 2001.

Neftel, A., Spirig, C., and Ammann, C.: Application and test of a simple tool for operational footprint evaluations, Environ. Pollut., 152, 644-652, doi:10.1016/j.envpol.2007.06.062, 2008.

Norman, M., Hansel, A., and Wisthaler, A.: $\mathrm{O}_{2}^{(+)}$as reagent ion in the PTR-MS instrument: Detection of gas-phase ammonia, Int. J. Mass Spectrom., 265, 382-387, doi:10.1016/j.ijms.2007.06.010, 2007.

Norman, M., Spirig, C., Wolff, V., Trebs, I., Flechard, C., Wisthaler, A., Schnitzhofer, R., Hansel, A., and Neftel, A.: Intercomparison of ammonia measurement techniques at an intensively managed grassland site (Oensingen, Switzerland), Atmos. Chem. Phys., 9, 2635-2645, 2009,

http://www.atmos-chem-phys.net/9/2635/2009/.

Nowak, J. B., Huey, L. G., Eisele, F. L., Tanner, D. J., Mauldin, R. L., Cantrell, C., Kosciuch, E., and Davis, D. D.: Chemical ionization mass spectrometry technique for detection of dimethylsulfoxide and ammonia, J. Geophys. Res.-Atmos., 107, 4363, doi:10.1029/2001JD001058, 2002.

Otjes, R. P. and Erisman, J. W.: Haalbaarheidstudie miniaturisering ammoniak analyser (Feasibility study on the diminution of ammonia analyser), ECN, Petten, NL, 1999 (in Dutch).

Pain, B. F., Phillips, V. R., Clarkson, C. R., and Klarenbeek, J. V.: Loss of nitrogen through ammonia volatilization during and following the application of pig or cattle slurry to grassland, J. Sci. Food Agr., 47, 1-12, 1989.

Reidy, B., Rihm, B., and Menzi, H.: A new Swiss inventory of ammonia emissions from agriculture based on a survey on farm and manure management and farmspecific model calculations, Atmos. Environ., 42, 3266-3276, doi:10.1016/j.atmosenv.2007.04.036, 2008.
Rochette, P., Guilmette, D., Chantigny, M. H., Angers, D. A., MacDonald, J. D., Bertrand, N., Parent, L. E., Cote, D., and Gasser, M. O.: Ammonia volatilization following application of pig slurry increases with slurry interception by grass foliage, Can. J. Soil Sci., 88, 585-593, 2008.

Søgaard, H. T., Sommer, S. G., Hutchings, N. J., Huijsmans, J. F. M., Bussink, D. W., and Nicholson, F.: Ammonia volatilization from field-applied animal slurry - the ALFAM model, Atmos. Environ., 36, 3309-3319, 2002.

Sommer, S. G. and Hutchings, N. J.: Ammonia emission from field applied manure and its reduction - invited paper, Eur. J. Agron., 15, 1-15, 2001.

Sommer, S. G., Génermont, S., Cellier, P., Hutchings, N. J., Olesen, J. E., and Morvan, T.: Processes controlling ammonia emission from livestock slurry in the field, Eur. J. Agron., 19, 465-486, doi:10.1016/s1161-0301(03)00037-6, 2003.

Spindler, G., Teichmann, U., and Sutton, M. A.: Ammonia dry deposition over grassland - micrometeorological flux-gradient measurements and bidirectional flux calculations using an inferential model, Q. J. Roy. Meteor. Soc., 127, 795-814, 2001.

Spranger, T., Klimont, Z., Sponar, M., Raes, C., Baker, S. M. H., Sutton, M. A., Gillespie, C., Sim Tang, Y., Vibeke Andersen, H., Ellerman, T., Flechard, C. R., and Hutchings, N. J.: Ammonia Policy Context and Future Challenges, in: Atmospheric Ammonia, edited by: Sutton, M. A., Reis, S., and Baker, S. M. H., 433-443, Springer, Dordrecht, 2009.

Sutton, M. A., Fowler, D., and Moncrieff, J. B.: The exchange of atmospheric ammonia with vegetated surfaces. 1. Unfertilized vegetation, Q. J. Roy. Meteor. Soc., 119, 1023-1045, 1993a.

Sutton, M. A., Fowler, D., Moncrieff, J. B., and Storetonwest, R. L.: The exchange of atmospheric ammonia with vegetated surfaces. 2. Fertilized vegetation, Q. J. Roy. Meteor. Soc., 119, 1047-1070, $1993 b$.

Thomas, R. M., Trebs, I., Otjes, R., Jongejan, P. A. C., Ten Brink, H., Phillips, G., Kortner, M., Meixner, F. X., and Nemitz, E.: An automated analyzer to measure surf ace-atmosphere exchange fluxes of water soluble inorganic aerosol compounds and reactive trace gases, Environ. Sci. Technol., 43, 1412-1418, doi:10.1021/es8019403, 2009.

Thompson, R. B. and Meisinger, J. J.: Gaseous nitrogen losses and ammonia volatilization measurement following land application of cattle slurry in the mid-Atlantic region of the USA, Plant Soil, 266, 231-246, 2004.

UNECE (United Nations Economic Comission for Europe): Protocol to the 1979 Convention on long-range transboundary air pollution to abate acidification, eutrophication and ground-level ozone, Geneva, www.unece.org/env/lrtap, 1999.

Vandre, R., Clemens, J., Goldbach, H., and Kaupenjohann, M.: $\mathrm{NH}_{3}$ and $\mathrm{N}_{2} \mathrm{O}$ emissions after landspreading of slurry as influenced by application technique and dry matter-reduction. 1 . $\mathrm{NH}_{3}$ emissions, Z. Pflanz. Bodenkunde, 160, 303-307, 1997.

Vayenas, D. V., Takahama, S., Davidson, C. I., and Pandis, S. N.: Simulation of the thermodynamics and removal processes in the sulfate-ammonia-nitric acid system during winter: Implications for PM2.5 control strategies, J. Geophys. Res.-Atmos., 110, D07S14, doi:10.1029/2004JD005038, 2005.

VDLUFA: Die Untersuchung von Sekundärrohstoffdüngern, Kultursubstraten und Bodenhilfsstoffen, edited by: Verband Deutscher Landwirtschaftlicher Untersuchungs- und 
Forschungsanstalten, VDLUFA-Verlag, 204 pp., Speyer, 2000.

Walker, J. T., Robarge, W. P., Wu, Y., and Meyers, T. P.: Measurement of bi-directional ammonia fluxes over soybean using the modified Bowen-ratio technique, Agr. Forest Meteorol., 138, 54-68, doi:10.1016/j.agrformet.2006.03.011, 2006.

Webb, E. K., Pearman, G. I., and Leuning, R.: Correction of flux measurements for density effects due to heat and water vapour transfer, Q. J. Roy. Meteor. Soc., 106, 85-100, 1980.

Whitehead, J. D., Twigg, M., Famulari, D., Nemitz, E., Sutton, M. A., Gallagher, M. W., and Fowler, D.: Evaluation of laser absorption spectroscopic techniques for eddy covariance flux measurements of ammonia, Environ. Sci. Technol., 42, 2041-2046, doi:10.1021/es071596u, 2008.
Wichink Kruit, R. J., van Pul, W. A. J., Otjes, R. P., Hofschreuder, P., Jacobs, A. F. G., and Holtslag, A. A. M.: Ammonia fluxes and derived canopy compensation points over non-fertilized agricultural grassland in The Netherlands using the new gradient ammonia - high accuracy - monitor (GRAHAM), Atmos. Environ., 41, 1275-1287, doi:10.1016/j.atmosenv.2006.09.039, 2007.

Wyers, G. P., Oties, R. P., and Slanina, J.: A continuous-flow denuder for the measurement of ambient concentrations and surface-exchange fluxes of ammonia, Atmos. Environ. A-Gen., 27, 2085-2090, 1993.

Yu, F. Q.: Effect of ammonia on new particle formation: A kinetic $\mathrm{H}_{2} \mathrm{SO}_{4}-\mathrm{H}_{2} \mathrm{O}-\mathrm{NH}_{3}$ nucleation model constrained by laboratory measurements, J. Geophys. Res.-Atmos., 111, D01204 doi:10.1029/2005JD005968, 2006. 